\title{
Meta
}

Journal des traducteurs

Translators' Journal

Kiraly, D. (2000): A Social Constructivist Approach to

Translator Education; Empowerment from Theory to Practice, Manchester, UK \& Northampton MA, St. Jerome Publishing, 207

p.

\section{Anne Malena}

Volume 48, numéro 4, décembre 2003

URI : https://id.erudit.org/iderudit/008733ar

DOI : https://doi.org/10.7202/008733ar

Aller au sommaire du numéro

Éditeur(s)

Les Presses de l'Université de Montréal

ISSN

0026-0452 (imprimé)

1492-1421 (numérique)

Découvrir la revue

Citer ce compte rendu

Malena, A. (2003). Compte rendu de [Kiraly, D. (2000): A Social Constructivist Approach to Translator Education; Empowerment from Theory to Practice,

Manchester, UK \& Northampton MA, St. Jerome Publishing, 207 p.] Meta, 48(4),

596-597. https://doi.org/10.7202/008733ar d'utilisation que vous pouvez consulter en ligne. 


\section{Kiraly, D. (2000): A Social Constructivist Approach to Translator Education; Empow-} erment from Theory to Practice, Manchester, UK \& Northampton MA, St. Jerome Publishing, $207 \mathrm{p}$.

This book is a welcome addition to the rapidly developing field of Translator Training. Social constructivist theories have been revolutionizing Second Language teaching for a while now and translation teaching has everything to gain from its insights. As Kiraly argues " $[\mathrm{t}]$ ranslators today cannot afford to be linguistic hermits, sitting alone behind a typewriter and surrounded only by dusty tomes. Translators are embedded in a complex network of social and professional activity" (p. 12). Such a standpoint stems from a collaborative view of society which has important implications for the way we guide students in developing the skills they will need as language mediators and full-fledged social agents.

The book is divided into nine sections dealing with the philosophy and key principles of constructivist theory for Translator Education and concrete suggestions for classroom instruction. Since his last book, Pathways to Translation (1995), Kiraly has come to see the cognitive science approach to translation teaching, based on the assumption that knowledge is the product of an individual mind, as incompatible with a view of learning as a process of social interaction. This book then seeks to displace an objectivist perspective to translation teaching and proposes some key principles of Social-constructivist Education and how to apply them. The aim is to ensure that graduating students are able to function autonomously and confidently in the professional world. Using his own classroom as a prototype, Kiraly suggests that other constructivist-minded teachers develop their own perspective to suit their particular curriculum and course design requirements. A very useful chapter follows on technology and how best to integrate computers and computer-based tools in a social constructivist classroom. Also useful are the suggestions made for assessment, such as the production of portfolios and peer evaluation, although much more thinking and discussion need to take place in this area to balance out institutional constraints with teaching philosophies.

The closing chapter, "From Dead Bodies and Talking Heads to Holistic Second Language Acquisition in the Classroom", emphasizes how mutually benefiting a communicative approach can be both for Second Language Acquisition and Translation Training. In North America such innovation may no longer be as controversial as Kiraly implies, given the sweeping reforms departments of Modern Languages have had to implement over the last few years in order to cope with budget restraints (see Malena). To view the student as an adult assuming responsibility for his or her own learning and engaging in dialogue with peers, teachers and professionals can no longer be considered revolutionary in today's world characterized by global communication and the sharing of information. More remains to be done, however, to raise the profile of teaching methodology in translator training through the exchange of views and experiences. Kiraly's book represents an important step in this direction in that it introduces useful theories to conceptualize how the focus of language and translation teaching needs to be shifted from being teacher-centered or learner-centered to "learning-centered".

Building on the work already done in foreign language learning, as opposed to second language acquisition, Kiraly outlines an approach inspired by Vygotsky's concept of learning as a social practice. Contrary to Piaget who viewed language as being the instrument of the gradual socialization of the child, Vygotsky saw the child as a social being from birth. According to him, the formative years are spent negotiating individuality through the social practice of language, a process which continues throughout one's lifetime. Thus the learning process precedes the developmental process in creating zones of proximal development (ZPD). The constructivist teacher will therefore provide just enough guidance to hold the student in his or her ZPD in order to facilitate learning. Through scaffolding, which Kiraly defines 
as "a flexible structure that emerges within the ZPD as a function of ongoing negotiations between the teachers and the learners" (p. 46), the student is gradually empowered towards autonomy.

Kiraly argues that the social constructivist approach is particularly well-suited to the training of translators since translator competence can be seen as "a creative, largely intuitive, socially-constructed, and multi-faceted complex of skills and abilities" (p. 49). In his perspective then the translation classroom should maintain a link with the real world through teaching based on "authentic situated action, the collaborative construction of knowledge, and personal experience" (p. 3). He insists on the importance of teachers being practising translators themselves and on involving students in the selection, negotiation, and completion of real jobs. This aspect of Kiraly's approach is one of the most convincing since the examples he gives and the suggestions he makes illustrate that, with adequate scaffolding, there is no need to reduce the complexity of a translation situation at any level. Students taking on authentic projects have to deal with every aspect of the job from finding it to negotiating a contract to producing an acceptable product. The teacher assumes ultimate responsibility and provides guidance when it is needed. Many questions come up over the course of the term, including those pertaining to ethics, technology, translation strategies, etc., and provide as many opportunities for collaborative learning. While, for a variety of reasons, it may not be suitable for every programme to include authentic projects, Kiraly's discussion does provoke thinking on the pedagogical possibilities offered by the use of authentic texts embedded in more or less authentic situations.

The book is proposed as a reflection on translator training rather than a set of recipes for curriculum planning and course design. The clearly outlined principles do suggest ways to implement a social constructivist approach without claiming that it be adopted wholesale. In fact, translator educators and programme administrators interested in this approach will need to adapt it to the needs and goals of their own institution, given their own particular constraints, the overarching teaching philosophy of their department, and the profile of their students as well as the market conditions these students are being trained to enter. Don Kiraly is acting as a pioneer in this area and the account he gives of his own teaching experience shows how he has developed his approach to suit the needs of the particular situation encountered at the University of Mainz in Germany. There is a need for further debate among translator trainers - and for more training of translator trainers although a few short term programmes have been created, among which Kiraly's own offering of a summer Certificate in Translation Teaching at the Monterey Institute for International Studies - and this book opens the door for discussion on how institutions can best respond to the needs of the international community of professional translators by the way they choose to train translators.

Anne Malena

University of Alberta, Edmonton, Canada

\section{REFERENCES}

Malena, A. (2002): «Altérité et intégration: le rôle de la traduction», Canadian Modern Language Review, 58-3, p. 386-401.

Vygotsky, L. S. (1962): Thought and Language, Cambridge, MA, MIT Press. 